\title{
Pengaruh pemberian ekstrak pasak bumi (Eurycoma longifolia Jack) terhadap kualitas spermatozoa tikus wistar (Rattus norvegicus)
}

\author{
${ }^{1}$ Bill C. A. Bogar \\ ${ }^{2}$ Lydia Tendean \\ ${ }^{2}$ Grace L. A. Turalaki \\ ${ }^{1}$ Mahasiswa Fakultas Kedokteran Universitas Sam Ratulangi \\ ${ }^{2}$ Bagian Biologi Fakultas Kedokteran Universitas Sam Ratulangi \\ Email: billbogar@ymail.com
}

\begin{abstract}
Infertility is an inability of couples to reproduce after carrying out sexual intercourses for at least a year without using any contraceptives. There are $10-15 \%$ couples worldwide who experience infertility problems and almost one half of them is on men. Spermatozoa qualities including concentration, motility, and morphology are used as an indicator for men's fertility. The utilization of herbal medicine (i.e. Eurycoma longifolia Jack extracts) is now being an alternative way to improve fertility among the community. This study was carried out to find the effects of Eurycoma longifolia Jack on spermatozoa qualities. This experimental study was conducted to nine male wistar rats (Rattus norvegicus) weighing from 200-250 grams, aging from 12-15 months. These nine adult rats were divided into 3 groups of 3 rats each. 400 and $600 \mathrm{mg} / \mathrm{kg} /$ day of Eurycoma longifolia Jack extracts were orally administrated to group 1 and 2 respectively, while group 3 were treated as control group. After 50 days, the animals of group 1, 2 and 3 were sacrificed. As a result, there is an improvement in qualities of spermatozoa which are statistically significant $(p<0,05)$ in group 2. Thus, provide the beneficial effects of $600 \mathrm{mg} / \mathrm{kg}$ Eurycoma longifolia Jack extracts on the qualities of spermatozoa.
\end{abstract}

Keywords: pasak bumi, spermatozoa

\begin{abstract}
Abstrak: Infertilitas adalah ketidakmampuan pasangan untuk dapat hamil setelah satu tahun berhubungan intim tanpa menggunakan kontrasepsi. Ada sekitar $10-15 \%$ pasangan mengalami masalah infertilitas dan hampir setengahnya masalah ada pada pria. Kualitas spermatozoa meliputi konsentrasi, motilitas dan morfologi spermatozoa merupakan salah satu indikator fertilitas pada pria. Penggunaan tanaman herbal atau yang lebih dikenal jamu telah menjadi pengobatan alternatif di masyarakat. Tanaman herbal yang dimaksud adalah pasak bumi. Penelitian ini bertujuan untuk mengetahui efek dari esktrak pasak bumi (Eurycoma longifolia Jack) terhadap kualitas spermatozoa. Penelitian ini menggunakan 9 ekor tikus wistar jantan (Rattus norvegicus) dengan berat badan 200-250 g berumur 12-15 bulan. Sembilan ekor wistar dibagi menjadi tiga kelompok, dan satu kelompok terdiri dari tiga ekor tikus wistar. Penelitian ini dilaksankan selama 50 hari. Esktrak pasak bumi (Eurycoma longifolia Jack) diberikan dengan dosis 400mg/kgBB per hari pada perlakuan 1 dan dosis $600 \mathrm{mg} / \mathrm{kgBB}$ per hari pada perlakuan 2. Setelah 50 hari hewan coba pada kelompok kontrol, perlakuan 1 dan perlakuan 2 diterminasi. Hasil penelitian memperlihatkan terjadi peningkatan kualitas spermatozoa yang signifikan secara statistik $(\mathrm{p}<0,05)$ pada perlakuan 2 terhadap kelompok kontrol. Hasil tersebut menunjukan bahwa Esktrak pasak bumi (Eurycoma longifolia Jack) pada dosis $600 \mathrm{mg} / \mathrm{kgBB}$ dapat meningkatkan kualitas spermatozoa.
\end{abstract}

Kata kunci: pasak bumi, spermatozoa 
Infertilitas merupakan ketidakmampuan pasangan untuk hamil, setelah bersenggama secara teratur tanpa alat kontrasepsi. Hasil penelitian menunjukan $10-15 \%$ pasangan mengalami kemandulan dan dari jumlah tersebut 40 - $50 \%$ penyebabnya adalah masalah pada pria. Kualitas sperma merupakan salah satu indikator fertilitas pada laki-laki. ${ }^{1}$ Beberapa aspek digunakan dalam penilaian kualitas sperma misalnya penilaian terhadap konsentrasi, motilitas dan morfologi sel spermatozoa. ${ }^{2}$ Kualitas sperma itu sendiri merupakan salah satu pemeriksaan rutin yang dilakukan untuk menilai fertilitas pria. Spermatogenesis adalah proses dimana sel germinal imatur mengalami pembelahan, diferensiasi dan miosis menjadi spematid yang bersifat haploid. $^{2}$ Faktor yang berperan dalam spermatogenesis salah satunya adalah faktor hormonal. Salah satu hormon yang berperan adalah hormon testosteron. ${ }^{3}$

Dalam mengatasi masalah infertilitas ada banyak alternatif yang bisa menjadi solusi misalnya dengan mengkonsumsi tanaman-tanaman berkhasiat atau disebut dengan tanaman herbal. Tanaman herbal di Indonesia lebih dikenal dengan istilah jamu atau obat tradisional. Adapun produk jamu ialah jamu dengan bahan dasar ekstrak pasak bumi (Eurycoma longifolia Jack). Pasak bumi (Eurycoma longifolia Jack) banyak digunakan di dalam obat-obatan tradisional karena dipercaya dapat meningkatkan gairah seks pria sehingga disebut tanaman afrodisiak. Pasak bumi dapat meningkatkan gairah seks pada pria, karena kandungan bahan aktifnya yang berupa berbagai mineral (Fe, Co, Mg, Zn), saponin, sterol, dan isoprenoid. Isoprenoid dan sterol diperlukan untuk sintesis homon steroid salah satunya berupa testosteron. Berbagai mineral tersebut juga berperan dalam maturisasi spermatozoa. ${ }^{4}$ Pasak bumi juga mempunyai kandungan kimia eurikomolakton dan amarolinda yang dapat meningkatkan libido dan mempunyai efek androgenik. ${ }^{4}$ Pada beberapa penelitian yang telah dilakukan peningkatkan hormon testosteron akibat pengaruh dari beta sitosterol yang merupakan kandungan bahan aktif pasak bumi yang struktur molekulnya mirip steroid dan bersifat androgenik, kemungkinan efeknya di dalam tubuh sama dengan testosteron dan berpengaruh langsung pada tingkat enzim mikrosomal dalam sel Leydig sehingga menaikkan kadar testosteron.,4-9

\section{METODE PENELITIAN}

Penelitian ini mengunakan metode eksperimental analitik dengan pendekatan post-test only control group design. Penelitian dilakukan di Laboratorium Biologi Fakultas Kedokteran Unsrat pada bulan November 2015 sampai Januari 2016. Sampel yang digunakan yaitu 9 ekor tikus wistar jantan (Rattus norvegicus) berumur 12 - 15 bulan dengan berat 200 250 gram.Sampel dibagi menjadi 3 kelompok yaitu kelompok kontrol $\left(\mathrm{P}_{0}\right)(\mathrm{n}=3)$, kelompok perlakuan $1\left(\mathrm{P}_{1}\right)(\mathrm{n}=3)$ dan kelompok perlakuan $2 \quad\left(\mathrm{P}_{2}\right)(\mathrm{n}=3)$. Sampel diberikan makan dan minum secara ad libitum. Kelompok perlakuan 1 dan kelompok perlakuan 2 diberikan ekstrak Eurycoma longifolia Jack dengan dosis masing-masing $400 \mathrm{mg} / \mathrm{kgBB} / \mathrm{hari}$ dan 600 $\mathrm{mg} / \mathrm{kgBB} /$ hari. Penelitian dilakukan selama 50 hari dan pada hari 51 sampel diterminasi.

\section{HASIL PENELITIAN}

Setelah dilakukan penelitian selama 50 hari pada 3 kelompok tikus wistar (Rattus norvegicus) yang telah diberikan ekstrak Eurycoma longifolia Jack didapatkan hasil rerata konsentrasi, motilitas dan morfologi spermatozoa masing-masing kelompok.

Pada Tabel 2 dapat dilihat hasil uji komparabilitas kualitas spermatozoa antara $\mathrm{P}_{1}$ dan kualitas spermatozoa $\mathrm{P}_{0}$. Tidak ada perbedaan bermakna konsentrasi spermatozoa antara $\mathrm{P}_{1}$ dan $\mathrm{P}_{0}(\mathrm{p}>0,05)$.

Tidak ada perbedaan bermakna motilitas normal spermatozoa antara $\mathrm{P}_{1}$ dan $\mathrm{P}_{0}$ $(\mathrm{p}>0,05)$.

Berdasarkan data pada Tabel 1, dilakukan uji komparabilitas dengan menggunakan independent sample T-test (Tabel 2 dan 3). 
Tabel 1. Rerata konsentrasi, motilitas dan morfologi spermatozoa

\begin{tabular}{cccccc}
\hline Kelompok & Konsentrasi (per & \multicolumn{2}{c}{ Motilitas (\%) } & \multicolumn{2}{c}{ Morfologi (\%) } \\
\cline { 3 - 6 } Sampel & $\mathrm{ml})$ & Normal & Abnormal & Normal & Abnormal \\
$\mathrm{P}_{0}$ & 25.833 .333 & 60 & 40 & 72 & 28 \\
$\mathrm{P}_{1}$ & 29.083 .333 & 30 & 70 & 72 & 28 \\
$\mathrm{P}_{2}$ & 48.683 .333 & 95 & 5 & 95 & 5 \\
\hline
\end{tabular}

Keterangan: Kelompol $\mathrm{P}_{0}$, kelompok tidak diberikan ekstrak pasak bumi (Eurycoma longifolia Jack). Kelompok $\mathrm{P}_{1}$, kelompok yang diberikan ekstrap pasak bumi (Eurycoma longifolia Jack) dengan dosis $400 \mathrm{mg} / \mathrm{kgBB}$. Kelompok $\mathrm{P}_{2}$, kelompok yang diberikan ekstrak pasak bumi (Eurycoma longifolia Jack) dengan dosis 600mg/kgBB.

Tabel 2 Pengujian Rerata Kualitas Spermatozoa Kelompok Perlakuan 1 Terhadap Kelompok Kontrol Dengan Uji T.

\begin{tabular}{lccc}
\hline \multicolumn{1}{c}{ Kualitas Spermatozoa } & Kelompok Perlakuan 1 & Kelompok Kontrol & $\mathrm{p}$ \\
\hline Konsentrasi & 29.083 .333 & 25.833 .333 & 0,764 \\
Motilitas Normal & 30 & 60 & 0,387 \\
Morfologi Normal & 72 & 72 & 0,719 \\
\hline
\end{tabular}

Tidak ada perbedaan bermakna morfologi normal spermatozoa antara $\mathrm{P}_{1}$ dan $\mathrm{P}_{0}$ $(\mathrm{p}>0,05)$

Pada Tabel 3 dapat dilihat hasil uji komparabilitas kualitas spermatozoa antara $\mathrm{P}_{2}$ dan kualitas spermatozoa kelompok $\mathrm{P}_{0}$. Hasil uji $\mathrm{T}$ pada tabel 3 menunjukkan ada perbedaan bermakna konsentrasi spermatozoa antara $\mathrm{P}_{2}$ dan $\mathrm{P}_{0}(\mathrm{p}<0,05)$; ada perbedaan bermakna motilitas normal spermatozoa antara $\mathrm{P}_{2}$ dan $\mathrm{P}_{0}(\mathrm{p}<0,05)$; dan ada perbedaan bermakna morfologi normal spermatozoa antara $\mathrm{P}_{2}$ dan $\mathrm{P}_{0}(\mathrm{p}<0,05)$.

Tabel 3. Pengujian Rerata Kualitas Spermatozoa Kelompok Perlakuan 2 Terhadap Kelompok Kontrol dengan uji T

\begin{tabular}{lccc}
\hline \multicolumn{1}{c}{ Kualitas Spermatozoa } & Kelompok Perlakuan 2 & Kelompok Kontrol & $\mathrm{p}$ \\
\hline Konsentrasi & 48.683 .333 & 25.833 .333 & 0,049 \\
Motilitas Normal & 80 & 60 & 0,026 \\
Morfologi Normal & 95 & 72 & 0,041 \\
\hline
\end{tabular}

\section{BAHASAN}

Pada penelitian ini didapatkan hasil analisis yang menunjukkan terdapat perubahan hasil kualitas spermatozoa antara kelompok perlakuan 1 terhadap kelompok kontrol dan kelompok perlakuan 2 terhadap kelompok kontrol. Hasil analisis perbandingan kualitas spermatozoa baik konsentrasi, motilitas normal maupun morfologi kelompok perlakuan 1 terhadap kelompok kontrol sesuai dengan tabel 4 menunjukan tidak ada perbedaan yang signifikan $\quad(p>0,005) \quad$ sedangkan perbandingan kualitas spermatozoa baik konsentrasi, motilitas normal maupun morfologi kelompok perlakuan 2 terhadap kelompok kontrol sesuai dengan tabel 5 menunjukan ada perbedaan yang siginifikan $(\mathrm{p}<0,05)$.

Perlakuan 1 diberikan ekstrak pasak bumi (Eurycoma longifolia Jack) dengan dosis $400 \mathrm{mg} / \mathrm{kgBB}$ dan perlakuan 2 diberikan ekstrak pasak bumi (Eurycoma longifolia Jack) dengan dosis $600 \mathrm{mg} / \mathrm{kgBB}$, penentuan dosis tersebut karena pada dosis tersebut dapat 
meningkatkan libido dan kadar hormon testosteron. ${ }^{9,10}$

Tidak adanya perbedaan yang signifikan kualitas spermatozoa kelompok perlakuan 1 terhadAp kelompok kontrol mungkin disebabkan dosis yang diberikan kurang sehingga kandungan yang terdapat dalam pasak bumi (Eurycoma longifolia Jack), yaitu isoprenoid dan sterol ${ }^{4}$ tidak dapat mempengaruhi kualitas spermatozoa walaupun pada dosis tersebut dapat meningkatkan libido terkait dengan meningkatnya hormon testosteron. ${ }^{10}$ Isoprenoid dan sterol merupakan senyawa aktif yang terdapat pada pasak bumi. Kedua bahan ini diperlukan untuk sintesis hormon steroid. ${ }^{11}$ Hormon steroid dalam hal ini adalah testosteron yang berperan dalam proses spermatogenesis.

Adanya perbedaan bermakna kualitas spermatozoa kelompok perlakuan 2 terhadap kelompok kontrol sesuai dengan hipotesis bahwa pemberian ekstrak pasak bumi (Eurycoma longifolia Jack) dapat meningkatkan kualitas spermatozoa. Peningkatan terjadi karena peran dari bahan aktif yang terkandung pada pasak bumi yaitu isoprenoid dan sterol. Peningkatan bahan aktif ini dalam tubuh akan diikuti dengan meningkatnya hormon testosteron dalam darah sehingga terjadi peningkatan proses spermatogenesis. Selain kedua bahan aktif tersebut, pasak bumi juga mengandung bahan aktif lain yaitu eurikomolaton dan amarolinda. Bahan ini akan memperbaiki aktivitas membran sel hipofisis anterior sehingga pelepasan LH dan FSH akan lebih banyak. ${ }^{1}$ Peningkatan $\mathrm{LH}$ dan FSH akan mempengaruhi organ testis. Aktivitas membran testis akan menjadi lebih baik sehingga afinitas reseptor LH pada sel Leydig akan meningkat. LH akan terikat pada reseptor dan akan merangsang pembentukan dan sekresi testosteron. FSH yang dihasilkan hipofisis akan merangsang sel sertoli untuk membentuk sex hormone binding globulin (SHBG), berfungsi untuk mengikat testosteron yang dihasilkan sel Leydig. Proses ini akan meningkatkan kadar testosteron dalam testis yang merupakan syarat untuk inisiasi terjadinya proses spermatogenesis. ${ }^{1,12}$ Eurikomolaton dan amarolinda juga mampu memperbaiki afinitas membran reseptor dan juga terhadap enzim 5- $\alpha$ reductase yang berperan dalam konversi testosteron menjadi bentuk lebih poten yaitu dehidrotestosteron (DHT). ${ }^{1} \quad$ Perbaikan afinitas membran dan enzim 5 - $\alpha$ reductase akan memudahkan testoseron untuk masuk ke dalam sel Leydig. DHT ini kemudian akan menyebabkan terlepasnya protein tertentu (Hsp 90) dari reseptor androgen sehingga memungkinkan DHT berikatan dengan reseptor androgen yang terdapat dalam sitoplasma. Kompleks reseptor-DHT ini kemudian akan masuk ke dalam inti sel dan berinteraksi dengan sekuens spesifik DNA. Penempelan ini akan menginduksi sintesis mRNA. Proses ini selanjutnya akan meningkatkan kejadian spermatogenesis dan terutama adalah spermiogenesis. ${ }^{1}$

\section{SIMPULAN}

1. Pemberian ekstrak pasak bumi (Eurycoma longifolia Jack) dengan dosis $400 \mathrm{mg} / \mathrm{kgBB}$ tidak dapat meningkatkan kualitas spermatozoa tikus wistar jantan (Rattus norvegicus).

2. Pemberian ekstrak pasak bumi (Eurycoma longifolia Jack) dengan dosis $600 \mathrm{mg} / \mathrm{kgBB}$ dapat meningkatkan kualitas spermatozoa tikus wistar jantan (Rattus norvegicus).

\section{SARAN}

1. Perlu dilakukan penelitian lebih lanjut tentang lama pemberian dan dosis minimal dan maksimal ekstrak pasak bumi (Eurycoma longifolia Jack).

2. Perlu dilakukan pada sampel yang lebih besar.

\section{DAFTAR PUSTAKA}

1. Ahmad J. Diference Of Influence of Giving Eurycoma Longifolia and Pimpinela Alpina Extract at Spraque Dawly Spermatogenesis [thesis]. [Universitas Diponegoro]; 2004.

2. Cooper TG, Noonan E, Eckardstein VS, Jacques A, Gordon Baker HW, 
Hermann B, et al. World Health Organization reference values for human semen characteristics. WHO. 2009;00:1-15.

3. Guyton AC, Hall Je. Medical Physiology. $11^{\text {th }}$ ed. Mississippi: Elsevier, 2006; p. 996-1010.

4. Hamzah S, Yusof A. The Ergogenic Effect pf Eurycoma Longifolia Jack. Br J Sports Med. 2003;37:464-470.

5. Serge C, Rex HA. Oestrogen and Spermatogenesis. The Royal Society. 2010;365:1517-35.

6. Fatmawati D. Efek Pemberian Sebuk Pasak Bumi terhadapat Motilitas dan Abnormalitas Sperma Mencit Semarang. 2009;1:159-67.

7. Wahab N, Mokhtar N, Halim N, Das S. The Effect of Eurycoma Longifolia on Spermatogenesis in EstrogenTreated Rats. Clinics. 2010;65:93-8.

8. Solomon M, Erasmus N, Henkel R. In vivo effects of Eurycoma Longifolia Jack (Tongkat Ali) extract on reproductive function in rats.
Andrologia. 2013;20:1-10.

9. Shinta N. Administration Of Pasak Bumi Extract (Eurycoma longifolia) Orally Increase Testosteron Hormone Level Of Old Male Rats (Rattus norvegicus) Strain Wistar [thesis]. [Universitas Udayana Denpasar]; 2015.

10.Ang $\mathbf{H}$, Lee $\mathbf{K}$. Effect Of Eurycoma Longifolia Jack On Libido In MiddleAged Male Rats. Freund Publishing House. 2002;13:249-54.

11.Trnk J. Isoprenoid metabolism: cholesterol and the others [home page on the internet]. nodate [citied 15 Januari 2016]. Available form: http://nas.lf3.cuni.cz/materialy/CVSE 1M0001/cholesterol-version-201001-05(4f59bcc191e00).pdf

12.Weinbauer G, Gromoll $M$, Nieslag $E$. Physiology of Testicular Function, in : Andrology Male Reproductive Health and Dysfunction, $3^{\text {rd }}$ ed. Germany: Spinger Verlag, 2010; p. 25-44. 